\title{
The Impact of Corporate Governance Mechanisms on Real and Accrual Earnings Management Practices: Evidence from Jordan
}

\begin{abstract}
Purpose - This paper investigates the impact of corporate governance (CG) mechanisms on real (REM), accrual-based earnings management (AEM) and REM/AEM interaction in Jordan following the 2009 Jordanian CG Code (JCGC).

Design/methodology/approach - The study used a sample of 108 Jordanian public firms covering 2010-2014. Hypotheses are tested using pooled OLS-regression models.

Findings - We find both institutional and managerial ownership constrain the use of REM and AEM. In contrast, both independent directors and large shareholders are found to exaggerate such practices, and CEO-duality is found to exaggerate REM only. However, foreign ownership does not appear to have a significant impact. We further find that managers use REM and AEM jointly to obtain the greatest earnings impact.

Practical implications - Our findings have important implications for policymakers, regulators, audit professionals and investors in their attempts to constrain earnings management (EM) practices and improve financial reporting quality in Jordan.

Originality/value - We believe this to be the first Jordanian study examining the relationship between CG mechanisms and both REM and AEM following the introduction of the 2009 JCGC, as well as the first in Jordan and the Middle East to examine board characteristics and REM. Moreover, it is the first to test for the potential substitution of REM and AEM since the 2009 JCGC enactment. As such, the findings draw attention to EM practices and the role of monitoring mechanisms in Jordan.
\end{abstract}

Keywords- Accrual earnings management, board characteristics, corporate governance, Jordan, ownership structure, real earnings management.

Paper type- Research paper. 


\section{Introduction}

Earnings is a critical reported number, and managers understand this to be a key metric for outsiders to assess not only the company's and the Chief Executive Officer's (CEO's) performance (Graham et al., 2005), but also executive compensation and future prospects of the firm (Xu et al., 2007). Thus, there are strong incentives to bias financial reports by manipulating the reported earnings to attain desired benchmarks. As such, earnings manipulation, even when not violating general accounting standards, may lead to inappropriate information about the firm (Rahman and Ali, 2006). Such EM has detrimental effects on the quality of financial reporting and may be reduced by applying good CG mechanisms (Uadiale, 2012) to improve the integrity of financial reports and act as a deterrent to manipulation. We focus on the monitoring and disciplining role of two critical internal mechanisms, specifically, the board of directors and ownership structure (Jensen and Meckling, 1976; Fama and Jensen, 1983; Gonzalez and Garcia-Meca, 2014).

Studies based on US and UK data show good CG can minimise earnings manipulation (e.g. Klein, 2002 and Peasnell et al., 2005). Here we investigate whether US and UK findings hold for Jordanian firms, extending research by investigating whether CG can assist in mitigating REM and AEM and impact substitution between REM and AEM. Differences in findings are to be expected as Jordan is a Middle East and North African (MENA) country where ownership is highly concentrated and investor protection is considered weak (World Bank, 2016).

CG reforms in Jordan are part of the country's economic reforms. The cornerstone of these reforms is the 2009 JCGC for companies listed on the Amman Stock Exchange (ASE). This code aims to (i) establish a clear framework regulating the relationships and management of ASE listees; (ii) to define rights, duties and responsibilities; and (iii) to safeguard rights of all stakeholders (JCGC, 2009). However, as the code is not legally binding, managers may still be tempted to manipulate earnings.

Consistent with prior studies in EM (e.g. Roychowdhury, 2006; Cohen et al., 2008; Cohen and Zarowin, 2010; Kuo et al., 2014; Alhadab et al., 2015, among others) we compute REM statistics by using the residuals from the Roychowdhury model (2006) and AEM ones by using residuals from the Kothari et al. (2005) model. In summary we have four key findings. First, board independence is significantly and positively related to REM and AEM in Jordan. Second, consistent with the "Convergence of Interests' Hypothesis", institutional ownership appears to constrain both REM and AEM; managerial ownership also appears to limit manipulation. Third, in line with the "Expropriation-of-the-Minority Shareholders Hypothesis", the presence of large shareholders appears to raise the incidence of both REM and AEM. Finally, Jordanian firms are found to follow an overall EM strategy, using both REM and AEM to obtain the desired earnings impact.

Our results contribute to the existing literature in EM and CG in five ways. First, this study is the first to investigate the impact of CG mechanisms on constraining REM and AEM after the introduction of JCGC in 2009. Previous EM research has largely been focused on developed countries and developing countries, which the OECD estimates will generate 60\% of world GDP by 2030 (OECD Development Centre, 2010), have been under researched. Second, previous research on CG and EM has focused primarily on AEM (e.g. Klein, 2002; Chen and Zhang, 2014; Gonzalez and Garcia-Meca, 2014, among others) rather than REM. Third, the study examines the impact of foreign share ownership on EM. Fourth, this is the first study that classifies Jordanian listed companies according to their one-digit SIC code in order to estimate the normal levels of REM and AEM based on an industry-year basis as in the original models (Kothari et al., 2005 and Roychowdhury, 2006). Fifth, the findings of this study are useful for policy and regulators who seek to devise CG mechanisms.

The reminder of this paper is structured as follows: section 2 reviews the previous light of the previous literature; section 3 describes our research design; section 4 presents the 
empirical results; robustness checks are presented in Section 5 and conclusions are presented in section 6 .

\section{Literature Review and Hypotheses Development 2.1 Earnings Management and Corporate Governance}

EM can be classified into two categories: AEM and REM (for example, Roychowdhury, 2006; Lo, 2008; Cohen et al., 2008; Cohen and Zarowin, 2010; Kuo et al., 2014; Alhadab et al., 2015). According to Dechow and Skinner (2000, p .240), AEM involves accounting choices within Generally Accepted Accounting Principles (GAAP), that aim to "obscure" or "mask" true economic performance. These choices include, fair value measurement, depreciation, deferred tax, goodwill impairments etc. (Healy and Palepu, 2001). In contrast to this, REM occurs when managers adjust the timing or structuring of transactions, investment and allocation of resources to alter accounting earnings within a current period (Dechow and Skinner, 2000; Roychowdhury, 2006). Hence, it is the operational practice that is "managed" in this case rather than accounting policy. Examples of REM include price discounting or offering lenient credit terms to temporarily increase sales; overproducing to report lower cost of goods sold; and cutting discretionary expenditures (Roychowdhury, 2006; Cohen et al., 2008; Cohen and Zarowin, 2010). The results of the survey by Graham et al. (2005) has drawn the attention of academic researchers to the managerial tendency to use REM and shows that it becoming more prevalent since the Sarbanes-Oxley Act in 2002 (e.g. Cohen et al., 2008; Cohen and Zarowin, 2010; Zang, 2012; Kuo et al., 2014, among others). This switch may have occurred for two possible reasons. Firstly, AEM may not provide sufficient oppportunity to bridge the gap to desired earnings (Roychowdhury, 2006; Cohen and Zarowin, 2010). Secondly, managing accruals is more likely to draw the attention of the auditor or regulator than real decisions about pricing and production (Graham et al., 2005).

A vital monitoring system to ensure the quality of the financial reporting process is "Corporate Governance"; this phrase is generally taken to refer to a system that aims primarily to resolve agency problems and reduce agency costs by aligning managerial interests with the interests of shareholders (Demsetz and Lehn, 1985). According to Cohen, et al (2002, p.587) "...one of the most important functions that corporate governance can play is in ensuring the quality of the financial reporting process".

The board of directors is a key internal CG mechanism for monitoring the quality and integrity of financial reports. Many scholars such as Jensen and Meckling (1976), Fama (1980), and Fama and Jensen (1983) perceive the board as an effective monitoring mechanism reducing agency conflicts between ownership and management. They contend that the board has the legal authority to protect shareholder interests by ratifying and monitoring managerial activities as well as evaluating and rewarding managers. According to Liu and Fong (2010), the more control the board exercises over managers (agents), the less opportunity for them to engage in selfish activities not consistent with maximizing shareholder wealth. Ownership structure can also be a control; Gonzalez and Garcia-Meca (2014 ,p.420) state ownership structure is "an internal control mechanism that focuses on the aspects that define the ownership of the company and refers to the manner in which titles or rights of representation redistribute the capital of the company in one or more individuals or legal entities". Wei, 2007, found that country differences in CG practices could be explained by different ownership structures. Accordingly, EM practices are also expected to differ between countries.

\subsection{Hypotheses Development}


Based on agency theory, monitoring strategies such as CG mechanisms, are introduced to align the interests of agent and principals, reducing, therefore, managerial opportunity over earnings. The following sub-sections briefly review the previous literature results regarding each mechanism, set up the research hypotheses and provide the rationale for each hypothesis.

\subsubsection{Board Structure Variables}

\subsubsection{Board Independence}

Board independence has been put forward as a strong CG mechanism for monitoring and restricting managerial opportunism. According to Fama (1980) and Fama and Jensen (1983), including independent directors improves the effectiveness of the board as a control mechanism. Independents have incentives to develop reputations as experts in decision making and monitoring, having generally gained expertise through acting as managers in other companies (Fama and Jensen, 1983). Thus, independent directors have a strong incentive to act as competent monitors (Fama, 1980; Fama and Jensen, 1983).

Drawing upon OECD and UK recommendations (OECD, 2004; and Cadbury, 1992), the 2009 JCGC recommends that at least one-third of board members should be independent. This approach is supported by findings in most previous literature, both for AEM, for example Beasley (1996) and Dechow et al. (1996), Klein (2002), Peasnell et al. (2005), Roodposhti and Chashmi (2011), Uadiale (2012) and Chen and Zhang (2014) and for REM, for example Osma (2008), Kang and Kim (2012) and Talbi et al. (2015). In a Jordanian context there has been one study undertaken by Abed et al. (2012) which researched the role of independent directors in deterring AEM before the 2009 JCGC introduction, finding no significant relationship between board independence and AEM. Hence, there is no previous research regarding independent directors and AEM in Jordan following the introduction of the 2009 JCGC and none at all regarding independent directors and REM. Given prior research and the 2009 JCGC recommendations, we postulate the following hypotheses;

Hla: Ceteris paribus, there is a significant negative relationship between the proportion of independent directors and REM in Jordan.

H1b: Ceteris paribus, there is a significant negative relationship between the proportion of independent directors and AEM in Jordan.

\subsubsection{Board Size}

As well as the independence, the size of the board may play an important role in enhancing the monitoring efficiency over EM decisions. Agency theory would suggest that larger boards are more likely to have the expertise, diversity and time to monitor management more effectively (Dalton et al., 1998). Previous AEM empirical results appear to be inconclusive with Klein (2002), Peasnell et al. (2005) and Ghosh et al. (2010) finding larger boards effective in constraining EM, but others, including Rahman and Ali (2006) and Ball and Shivakumar (2008), concluding the reverse. In the REM literature, Kang and Kim (2012) provide evidence that REM decreases as board size increases, whilst Talbi et al. (2015) finds the opposite and others (e.g. Osma, 2008) find no association. The current study is more 
concerned with the monitoring role of the board, hence, the view that larger boards with more independents, have more monitoring capacity leads to the following hypotheses:

H2a: Ceteris paribus, there is a significant negative relationship between board size and REM in Jordan.

H2b: Ceteris paribus, there is a significant negative relationship between board size and AEM in Jordan.

\subsubsection{CEO-duality}

From an agency theory perspective, separating CEO and board chair positions is thought to improve monitoring, otherwise one person has excessive power (Fama and Jensen, 1983; Jensen, 1993). An opposing viewpoint is that this "CEO-duality" can lead to an increase in the value of the firm because of centralisation and enhanced coordination (for example see Davis et al., 1997). Dechow et al. (1996), Klein (e.g. 2002) and Roodposhti and Chashmi (2011), among others, link CEO-duality to raised AEM, However, other empirical studies such as Beasley (1996), Peasnell et al. (2005) and Rahman and Ali (2006) report no association.

The REM literature is also inconclusive on CEO-duality. Ge and Kim (2014) report a link between CEO-duality and REM, yet Garven (2015) and others find no relation. Following the OECD and UK, the 2009 JCGC has recommended no CEO-duality. To the best of our knowledge, this is the first study to examine the impact of CEO-duality on REM in Jordan and in the Middle East region overall. Given the balance of research and the JCGC guidelines, we postulate:

H3a: Ceteris paribus, there is a significant positive relationship between CEO-duality and REM in Jordan.

H3b: Ceteris paribus, there is a significant positive relationship between CEO-duality and AEM in Jordan.

\subsubsection{Ownership Structure Variables}

\subsubsection{Managerial Ownership}

According to Jensen and Meckling's (1976) "Convergence of Interests' Hypothesis", managerial ownership can play a role in reducing conflict between managers and shareholders as it encourages managers to act as shareholders. However, a high level of managerial ownership, the "Entrenchment Hypothesis", provides managers with significant power and opportunity for EM (Morck et al., 1988). Previous AEM empirical results appear to be inconclusive; both Ali et al. (2008) and Alves (2012) find AEM negatively related to managerial ownership, but Teshima and Shuto (2008) find a positive relationship. Lin and Hwang (2010) in their meta-analysis, drawing on 48 prior studies, report a positive relationship between stock ownership by audit committee members and EM, supporting a more focused variant of the entrenchment hypothesis. More recently, Gonzalez and Garcia-Meca (2014) show a non-linear relation between insiders' ownership and discretionary accruals that imply that managerial ownership is a mechanism that may constrain the use of discretionary accruals only when 
insider ownership is low. Within the more limited REM research, Cohen et al. (2008) reports managerial ownership being linked to reduced REM , yet Liu and Tsai (2015) find no effect in Taiwan.

In Jordan, consistent with the entrenchment hypothesis, Al-Fayoumi et al. (2010) find managerial ownership increasing AEM. This finding was before the 2009 JCGC and only included the industrial sector. Recently, Ramadan (2016) finds that managerial ownership is inversely associated with AEM. Given this and other previous research, we propose the following hypotheses:

H4a: Ceteris paribus, there is a significant negative relationship between managerial ownership and REM in Jordan.

H4b: Ceteris paribus, there is a significant negative relationship between managerial ownership and AEM in Jordan.

\subsubsection{Institutional Ownership}

Sophisticated stockholders such as institutional investors (Chung et al., 2002) may constrain managerial opportunistic EM because they have the ability and resources to monitor, discipline and influence managerial decisions (Monks and Minow, 2008). According to Jung and Kown (2002), the information content of earnings increases significantly with institutional holdings. However, for AEM, overall evidence is mixed with Chung et al. (2002) and Cheng et al. (2013) finding a significant negative relationship between AEM and institutional investors, but other studies, such as Roodposhti and Chashmi (2011), find a positive relationship.No significant relationship is found by Peasnell et al. (2005), Alves (2012) and Chen and Zhang (2014). Within REM research, Bushee (1998), Roychowdhury (2006), Zang (2012), Liu and Tsai (2015) and others find that institutional investor ownership is correlated with reduced EM. In Jordan, Ramadan (2016) also finds a negative association in industrial firms. Given this, the following hypotheses are formulated:

H5a: Ceteris paribus, there is a significant negative relationship between institutional ownership and REM in Jordan.

H5b: Ceteris paribus, there is a significant negative relationship between institutional ownership and AEM management in Jordan

\subsubsection{Foreign Ownership}

Foreign investors may have a positive CG effect as they may have more power to monitor corporations than local investors (Young et al., 2008). The limited previous literature offers two competing views regarding this issue; "the information asymmetry hypothesis" and "the knowledge spillover hypothesis" (Guo et al., 2015). Guo et al list a number of potential positive spillover effects from the presence of foreign investors with the knowledge spillover hypothesis suggesting that the superior knowledge of foreign investors can restrain REM. In line with this hypothesis, Ben-Nasr et al. (2015) show that the presence of foreign ownership is associated with: (i) lower abnormal accruals, (ii) higher earnings quality and (iii) more persistent earnings, supporting the notion that foreign investors require higher quality 
accounting information, However, 'the information asymmetry hypothesis" implies that the presence of foreign ownership may motivate managers to take advantage of their greater local knowledge and to engage in earnings manipulation to achieve desired financial results as found by Aharony et al. (2000) in China. Research of foreign ownership and REM is very limited; Guo et al. (2015) show that foreign investors do play an independent role in restraining REM activities.

Jordan is attractive for foreign investors (ILO, 2013) with a relatively open economy. Hence, foreign investment in the ASE is one of the highest in the world (OECD, 2006), comprising 49\% of market capitalisation (ASE Annual Report, 2015). According to Khanna and Palepu (2000), as emerging markets become more integrated into the world economy, foreign investors exert a valuable monitoring role on corporate management. Hence, we postulate:

H6a: Ceteris paribus, there is a significant negative relationship between foreign ownership and REM in Jordan.

H6b: Ceteris paribus, there is a significant negative relationship between foreign ownership and AEM in Jordan.

\subsubsection{Large shareholder Ownership}

Two competing hypotheses exist in the previous literature regarding the role of concentrated ownership in the firm; "The Efficient Monitoring Hypothesis" and "The Expropriation-of-the-Minority Shareholders Hypothesis". According to "The Efficient Monitoring Hypothesis', large shareholders play a significant role in monitoring managers and reducing their opportunistic behaviour (Jensen and Meckling, 1976; Fama and Jensen, 1983), because they have both an interest in profit maximisation and enough control to have their interest respected (Shleifer and Vishny, 1997). In a Latin American context, Gonzalez and Garcia-Meca (2014) report that the largest shareholder only constrains AEM when their ownership is not extremely high. An alternative theory, "The Expropriation-of-the-Minority Shareholders Hypothesis" argues that when ownership structures become more concentrated, controlling shareholders may act opportunistically against the interests of minority shareholders to increase their private wealth (for example, Lemmon and Lins, 2003).

Limited previous research in Jordan includes Al-Fayoumi et al. (2010), who find that block-holders in industrial companies have no significant impact on constraining AEM. However, Ramadan (2016) finds equity concentration reduces EM in industrial firms. These conflicting results may be a result of the different time periods. In Jordan, like many Middle East and emerging markets, large shareholdings, often families, are common (World Bank, 2004). Gonzalez and Garcia-Meca (2014) find concentrated ownership structures cause CG problems; this may well be the case in Jordan and hence:

H7a: Ceteris paribus, there is a significant positive relationship between the largest shareholder ownership and REM in Jordan. 
H7b: Ceteris paribus, there is a significant positive relationship between the largest shareholder ownership and AEM in Jordan.

\section{Data and Methodology}

3.1 Sample and Data

The sample is Jordanian firms listed on the ASE from 2010 to 2014. Data on REM. AEM and CG variables are hand-collected from the annual reports of the sample firms that are publicly available on the ASE website. The study covers two sectors, the industrial and the service sectors; following previous literature on EM, the financial sector is excluded. The exclusion of these institutions results in a potential sample size of 133 firms. Excluding firms with missing CG data ${ }^{1}$, gives a final sample of 108 firms and 540 firm-year observations (see Table 1); 53 firms belong to the service sector and 55 to the industrial sector. Although the analysis covers the 2010 to 2014 period, 2008 and 2009 corporate data is collected to compute REM measures.

\section{INSERT TABLE 1 ABOUT HERE}

The study uses the one- digit SIC Code classification for six different industries with a minimum of five companies in each industry. Additionally, (similar to Zang, 2012 and Alhadab et al., 2015), the top and bottom 1 per cent of independent and dependent variables are winsorized to eliminate the effect of outlier bias. Given the secretive nature and inadequate disclosure of Jordanian reporting along with the absence of any databases that provide financial data and governance information, the hand collected data used in this analysis is unique and valuable.

\subsection{Earnings Management Measurement}

\subsubsection{Real Earnings Proxy}

Following previous research, we used the Roychowdhury model (2006) to estimate the REM proxy. This model focuses primarily on three significant operational activities through which managers may manipulate earnings. These activities include; (i) sales manipulation through increasing price discounts or offering more lenient credit terms, (ii) reduction in discretionary expenditures, such as reducing the research and development (R\&D), advertising, selling and administrating (SG\&A) expenses, and (iii) overproduction to report lower COGS. According to Roychowdhury (2006), managers may boost sales by using discounts or lenient credit terms in the current period, this is likely to lead to raised production costs, reduced margins and a fall-back in sales in the following year. Therefore, we expect an abnormally low operating cash flow (ABCFO) in the current period as a result of sales manipulation (Eq. 1). Alternatively, to manage earnings upward, firms can overproduce inventory to report a high operational margin, hence a higher value of the residual ABPROD, see Eq. (2). Managers can also manipulate earnings by reducing discretionary expenditures, so, Eq. (3) tests for lower

\footnotetext{
${ }^{1}$ Missing corporate governance variables are mainly due to the lack of disclosure by some of the sample firms.
} 
abnormal discretionary expenses (ABDISXP). The models are estimated for each year and for each industry cluster with at least six companies.

$$
\begin{gathered}
\frac{C F O_{i t}}{T A_{i t-1}}=a_{0}+\beta 1 \frac{1}{T A_{i t-1}}+\beta 2 \frac{S_{i t}}{T A_{i t-1}}+\beta 3 \frac{\Delta S_{i t}}{T A_{i t-1}}+\varepsilon_{i t}(1) \\
\frac{P R O D_{i t}}{T A_{i t-1}}=a_{0}+\beta 1 \frac{1}{T A_{i t-1}}+\beta 2 \frac{S_{i t}}{T A_{i t-1}}+\beta 3 \frac{\Delta S_{i t}}{T A_{i t-1}}+\beta 4 \frac{\Delta S_{i t-1}}{T A_{i t-1}}+\varepsilon_{i t} \\
\frac{D I S X P_{i t}}{T A_{i t-1}}=a_{0}+\beta 1 \frac{1}{T A_{i t-1}}+\beta 2 \frac{S_{i t-1}}{T A_{i t-1}}+\varepsilon_{i t}(3)
\end{gathered}
$$

Where, $C F O_{i t}$ is cash flow from operations of firm i in year t, $T A_{i t-l}$ represents total assets at the end of year $\mathrm{t}-1, S_{i t}$ is net sales for firm $\mathrm{i}$ in year $\mathrm{t}, \Delta S_{i t}$ is changes in net sales for firm $\mathrm{i}$ between year $\mathrm{t}-1$ and year $\mathrm{t}$, and $\varepsilon_{i t}$ is the regression residuals which represent our proxy for abnormal cash flow from operations. $P R O D_{i t}$ is firm i's production costs in year t, which equals the sum of the costs of goods sold plus changes in inventory, and $\varepsilon_{i t}$ is the regression residuals which represent our proxy for abnormal production costs. DISXP ${ }_{i t}$ is the discretionary expenses including selling, general and administrative expenses, $R \& D$, and advertising for firm $\mathrm{i}$ in year $\mathrm{t}$, and $\varepsilon_{i t}$ is the regression residuals which represent our proxy for abnormal discretionary expenditures. In addition, we construct an overall proxy, Eq. (4), by combining the aforementioned individual proxies. The aggregate real management proxy is expressed as:

\section{REM_ALL = -Abnormal cash flow from operations + Abnormal production costs- Abnormal discretionary expenses (4)}

Consistent with Cohen and Zarowin (2010) and many others, the larger REM_ALL the greater the implied use of REM.

\subsubsection{Accrual Earnings Proxy}

This study uses discretionary accruals as a proxy for AEM behavior as estimated by Dechow et al.'s (1995) cross-sectional version of the Modified Jones model. As suggested by Kothari et al. (2005), ROA is added to the model in order to control for extreme operating performance as this can bias the discretionary accruals estimation (for example Cohen et al., 2008; Alhadab et al., 2015). The model is estimated cross-sectionally each year for each industry. Discretionary accruals are the residuals of this accrual expectation model.

$$
\frac{T A C C_{i t}}{T A_{i t-1}}=a_{0}+\beta 1 \frac{1}{T A_{i t-1}}+\beta 2 \frac{\Delta R E V_{i t}-\Delta R E C_{i t}}{T A_{i t-1}}+\beta 3 \frac{P P E_{i t}}{T A_{i t-1}}+\beta 4 R O A_{(i t ~ o r ~ i t-1)}+\varepsilon_{i t}(5)
$$

Where, TACC it is the total accruals, $T A_{i t-1}$ is the book value of total assets of firm $i$ at the end of year $\mathrm{t}-1, \triangle R E V_{i t}-\triangle R E C_{i t}$ is sales revenues of firm $\mathrm{i}$ in year $\mathrm{t}$ less revenues in year $\mathrm{t}$ $-1, \triangle R E C$ is the change in accounts receivables. $P P E_{i t} / T A_{i t-l}$ is gross property, plant and equipment of firm $\mathrm{i}$ at the end of year $\mathrm{t}$ scaled by $T A_{i t-1}, R O A_{i t}$ is the return on assets, which is earnings before extraordinary items scaled by lagged total assets, $\alpha \beta 1 \beta 2 \beta 3 \beta 4$ are estimated parameters, and $\varepsilon$ is the residual that represents our proxy for discretionary accruals.

The main objective of our study is to measure the impact of CG mechanisms on REM and AEM in Jordan after the 2009 JCGC introduction. Hence, the absolute values of the residuals from Roychowdhury's model (2006) and Kothari et al. (2005) are used in the multivariate analyses in our study. 


\subsection{Regression Models}

Following previous REM and AEM literature (e.g. Osma, 2008; Gonzalez and GarciaMeca, 2014; Chen and Zhang, 2014 among others), the present study uses the following model to investigate whether board characteristics and ownership structure are able to constrain REM and AEM in the Jordanian context.

$$
\begin{gathered}
\text { EM }_{i t}=\alpha 0+\beta_{1} \text { BIND }_{i t}+\beta_{2} \text { BSIZE }_{i t}+\beta_{3} \text { CEODUAL } \\
i t
\end{gathered}
$$

The dependent variable, $E M$, is either the real or accrual earnings proxy. When it is the real proxy; it will be tested as each of the three individual real earnings proxies and as the aggregate proxy. When $E M$ is the accrual proxy; it is the abnormal discretionary accruals $(A B D A C C)$. The independent variables are detailed in Appendix 1 as are the firm characteristic variables that might affect the level of EM and the five controls that potentially affect earnings levels and quality. Thus, without any prediction of the coefficient's signs, these variables are incorporated into this study to distinguish their effects on REM and AEM. Finally, the models also control for industry and year fixed effects.

We further test for the potential substitution between REM and AEM. Following Ge and Kim (2014), Doukakis (2014), and others, the abnormal discretionary accruals proxy is added as an independent variable to the main model of our study. A negative (positive) coefficient on AEM would be interpreted as evidence of a substitutive (complementary) relation between REM and AEM in the Jordanian context. Further, there have been some minor necessary changes to the control variables for this model:

$$
\begin{aligned}
& \mathrm{REM}_{i t}=\alpha 0+\beta_{1} A E M_{i t}+\beta_{2} \text { BIND }_{i t}+\beta_{3} \text { BSIZE }_{i t}+\beta_{4} C E O D U A L_{i t}+\beta_{5} M A N G O W_{i t}+ \\
& \beta_{6} I N S T O W_{i t}+\beta_{7} \text { FOREOW }{ }_{i t}+\beta_{8} L_{\text {LRGST }}+\beta_{i t} \text { FSIZE }_{i t}+\beta_{10} \text { NOA }_{i t-1}+\beta_{11} \text { MKTSH }_{i t}+ \\
& \beta_{12} B I G 4_{i t}+\beta_{13-17 I N D D U M_{i t}}+\beta_{18-21} \text { YEARDUM }{ }_{i t}+\varepsilon_{\text {it }} \text { (7) }
\end{aligned}
$$

Where, the model is run with $R E M$ as the aggregate measure (REM_ALL), and also as the two sub-aggregate measures $(R E M 1 \text { and } R E M 2)^{2}$, defined in Appendix 1 . The augmented control variables are also in Appendix 1.

\section{Results and Discussions}

\subsection{Descriptive Statistics}

Table 2 is divided into two panels; Panel A reports the regression coefficients used to estimate 'normal' level of proxies; it shows the mean coefficients and t-statistics from standard errors across industry-years. Panel B reports the descriptive statistics for the main variables used in the analysis classified by group. As can be seen from Panel A, the estimated regression coefficients for EM proxies are consistent with prior studies (for example, Roychowdhury, 2006 and Kang and Kim, 2012). The average adjusted R $^{2}$ s across industry-years show reasonable explanatory power and are consistent with those produced by Roychowdhury (2006) and Zang (2012). Similar to previous studies, such as Zang (2012), Kang and Kim (2012), Goh et al. (2013) and Kuo et al. (2014), the means of EM proxies in this study are almost zero, implying that the models fit the data fairly well, consistent with Hayes $(2009$, p.282). The abnormal cash flow from operations in Jordan ranges from -0.047 to 0.046 which is rather lower

\footnotetext{
${ }^{2}$ Following previous literature such as Kuo et al. (2014), Cohen and Zarowin (2010), the present study divides the aggregate measure of REM into two sub-aggregate measures to avoid any double counting problems.
} 
than the US range of Ge and Kim (2014a), though comparable to the Korean findings of Goh et al. (2013).

\section{INSERT TABLE 2 ABOUT HERE}

The medians and ranges of EM variables - ABPROD, ABDISXP, REM_ALL, REM1, REM2 $A B D A C C$ - are largely in line with previous studies (for example Kuo et al., 2014; Ghosh et al., 2010). For Board variables, Panel B shows that the mean (median) BIND is $0.34(0.28)$, suggesting that just less than half of Jordanian firms are broadly in line with ASE recommendations of at least one third independent board members. The mean (median) of BSIZE is 8.09 (8) whilst the mean (median) of CEO duality (CEODUAL) is 0.17 (0), which means that about $83 \%$ of Jordanian firms follow the ASE recommendations. For ownership structure variables, Panel B shows that the mean (median) of managerial ownership is 0.50 $(52 \%)$ which is a very high relative to other emerging countries, such as $19.7 \%$ in Saudi Arabia (Alghamdi, 2012) and $9.9 \%$ in Malaysia (Ali et al., 2008). Institutional ownership shows a mean (median) of 39\% (37\%). Foreign ownership in Jordanian industrial and service firms has a mean (median) of $17 \%(0.07)$, rather lower than the whole market proportion due to high foreign ownership in the excluded finance sector. Finally, largest shareholder ownership has a mean of 36\%, confirming high concentration in Jordan compared to developed markets.

Panel B also shows a higher total debt to total assets ratio for Jordanian firms those in developed countries (see Zalata and Roberts, 2015). As with Kang and Kim's (2012) Korean sample, there is a low return (ROA), though the market to book ratio is higher than that reported for Korea by Goh et al. (2013). Only 37\% of Jordanian firms have BIG4 auditors. The small market share numbers are due in part to the need to define industry broadly, using just the first digit of the standard industry code, in order to achieve a useable number of observations within each industry classification.

Table 3 provides the Pearson correlations between CG variables and other firm-specific variables. The table reveals that the proxies for the hypotheses are not highly correlated with one another or with the control variables, suggesting that multicollinearity is not a problem.

\section{INSERT TABLE 3 ABOUT HERE}

\subsection{Multivariate Analysis}

\subsubsection{Corporate Governance, Real and Accrual-based Earnings Management}

Table 4 reports the regression results of the models. Columns (1-5) report the results where each of the REM and AEM proxies (ABCFO, ABPROD, ABDISXP, REM_All, and $A B D A C C)$ serve as the dependent variable, respectively. The results of the multivariate regression analyses are reported in $p$ values based on Newey and West standard errors, correcting for the impact of both heteroscedasticity and autocorrelation problems. The data do not suffer from multicollinearity problems as the highest variance inflation factor (VIF) is 2.53. 


\section{INSERT TABLE 4 ABOUT HERE}

As can be seen from the table, board independence has a positive and significant coefficient at the 1 or $5 \%$ level in all model variants, implying that independent boards in Jordan are more likely to engage both REM and AEM. This finding is consistent with Sun and Liu (2016). According to Ge and Kim (2014), this positive relation can be a result of the market pressure exerted from tough board performance monitoring from independent board members which may lead to a decrease in managerial commitment to long-term goals and a push to REM for short-term targets. Osma (2008) finds UK managers might hide relevant information from the board, compromising independent directors' decision. This might be the case in Jordan too. Also, independent directors in Jordan may also be insufficiently independent; Al-Jazi (2007) finds nepotism is common in appointments due to the influence of block-holders and independent directors may be compromised by private relationships. The market for independent directors in Jordan may also be immature. Whilst they might lack the accounting sophistication needed to detect REM, when it comes to discretionary expenditures, independent directors appear to exert some control.

When using ABDISXP as a proxy for REM, the board size shows a significant and positive relationship, indicating that larger boards are more likely to reduce discretionary expenditures in order to increase current earnings. This might be due to family dominance on boards and appointments based on kinship or friendship. This result is also supported by previous REM studies, for example Talbi et al. (2015) and Kang and Kim (2012). Further, in line with Ge and Kim (2014), REM through over-production is more prevalent with CEOduality.

Consistent with the "Convergence of Interests' Hypothesis", managerial ownership is found, to some extent, to be useful in mitigating REM through sales manipulation and discretionary accruals. The $A B D A C C$ result is also significant and confirms the results of others, including Ali et al. (2008) and Klein (2002). Institutional investor ownership reduces REM through sales manipulation and through discretionary expenditures; this finding is consistent with previous REM studies, including Roychowdhury (2006) and Zang (2012) and the $A B D A C C$ finding is also consistent with other AEM studies. This implies that sophisticated institutional investors in Jordan have a greater ability to analyze the long-term implications of current managerial actions and act as a disincentive for managers to engage in EM. Foreign ownership (FOREOW) is insignificant in all models. Dvorak (2005) suggests distance educes ineffectiveness.

LARGST is significant and positive, as expected, which means block-holders push managers to engage in EM through sales manipulation and through AEM. As mentioned before the high degree of ownership concentration is usually in the form of family-controlled businesses (ROSC, 2004). Further, controlling shareholders have incentives to maximize the earnings with the intent of increasing the share price to obtain more benefits from minority shareholders through inflating the share price (Chen and Zhang, 2014).

FSIZE is significant and negative, indicating that larger firms in Jordan are less likely to manage earnings through sales manipulations and discretionary accruals. This result is supported by Ali et al. (2008), Goh et al. (2013), and Ge and Kim (2014). Consistent with Jiang et al. (2008), who highlight that leverage changes may have various effects on EM, leverage in our study is found to be significant and positively linked to $A B C F O$ and $A B D A C C$, perhaps indicating that high leverage may lead to EM to avoid debt covenant violation. This finding is consistent with the findings of other papers including Cohen and Zarowin (2010) and Chen and Zhang (2014). Similarly, ROA is found to be significant and positively impacting REM, indicating that better performing firms in Jordan are more likely to engage in REM through 
sales manipulation. We also find that firms with high growth opportunities are more likely to engage in REM. Finally, consistent with the results of Doukakis (2014) and Zang (2012), having a BIG4 audit has no impact in mitigating REM nor AEM in Jordan.

\subsubsection{Potential Substitution between Real and Accrual-based Earnings Management}

To test for substitution, following Ge and Kim (2014), Doukakis (2014), and others, the abnormal discretionary accruals proxy is incorporated as an independent variable in the main REM model; a positive (negative) coefficient on AEM would be interpreted as evidence of a complementary (substitutive) relation between REM and AEM. The aggregate measure (REM_ALL) is used as a dependent variable. Further, two sub-aggregate measures REM1 and REM2 are used, because aggregating the three REM measures together into one measure may result in a double discounting problem. Table 5 reports the results of multivariate regression analysis for this model. All reported $p$ values are based on Newey and West procedures.

\section{INSERT TABLE 5 ABOUT HERE}

There is a strong positive relationship between REM and AEM in all models (t-statistic 4.97, 6.61, and 8.79, respectively), indicating that Jordanian firms use both REM and AEM as complements to each other with a combined EM strategy. This finding is similar to that reported in Taiwan by Chen et al. (2012), attributing this to the country's weak investor protection. BIG4 remains insignificant, implying managers do not need to switch to AEM to REM in order to avoid audit scrutiny. All other variables exhibit the same directional relationships as before, providing support for the results from the previous analysis.

\section{Robustness Checks}

\subsection{Composite Measure of Board and Ownership Variables}

Following Sun and Cahan (2009), we aggregate the individual governance quality scores as this is more likely to give a richer presentation of board and ownership structure quality. Jiang (2008) and Zalata and Roberts (2015) have generated composite measures of board and audit committee governance quality and examined the relationship between the governance score and financial reporting quality. Accordingly, we compute a composite measure of governance quality. The direction of the relationship between individual measures of CG and board and ownership structure governance quality is not always clear i.e. large sized boards might enhance the monitoring effectiveness or might harm it. Thus, following Sun and Cahan (2009) and Zalata and Roberts (2015), we used the sign of each individual measure under the main analysis in order to establish the governance quality direction. The composite measure is the sum of each individual variable score where the higher sum reflects an effective board and ownership structure.

INSERT TABLE 6 ABOUT HERE 
As can be seen from Table 6, there is a strong evidence of the ability of CG to determine the overall level of REM. In particular, the composite measure of CG (GOVSCOR) appears to have a significant negative relationship with REM manipulations through sales manipulations and overproduction (t-statistic $=-3.35$, and -1.77 , respectively). However, there is a significant and positive relationship between GOVSCOR and ABDISXP, indicating that tightening CG mechanisms appears to increase REM by decreasing the discretionary expenses. According to Ewert and Wagenhofer (2005) and others, firms tend to manipulate their business activities to manage earnings when tighter accounting standards and/or regulation reduces their ability to manage accruals. As expected, the table also shows that there is a significant negative relationship between GOVSCOR and $A B D A C C$, indicating that a strong CG structure can effectively decrease EM through AEM. The results for control variables are similar to that reported in the main analysis. When comparing these results with the results under the main analysis, it can be concluded that the significance level for the composite measure is higher than the level for each variable separately, suggesting that the board and ownership structure combine as a system.

\section{Conclusion}

The present paper has investigated the impact of CG mechanisms on both REM and AEM, and their potential interaction. Three types of REM and the abnormal discretionary accrual for AEM are considered. For internal CG mechanisms, board characteristics are examined along with ownership structure. Using panel data from Jordanian public firms over the 2010-2014 period, the empirical results reveal that CG does influence companies' decisions to manipulate reported earnings. Both institutional ownership and managerial ownership are found to constrain REM and AEM. In contrast, independent directors and having a large shareholder are found to exaggerate the incidence of using both REM and AEM, while CEOduality is found to exaggerate REM only. Foreign ownership does not appear to have any significant impact. We find that REM and AEM are used in a complimentary manner to obtain desired earnings impact.

Our results provide government and regulators with important information, linking CG to reporting quality. In this study, in contrast to the recommendations of the 2009 JCGC and conventional wisdom, the results show that independent directors exacerbate rather than reduce the prevalence of opportunism. Thus, policymakers must consider the characteristics of the institutional environment before applying further CG reforms. Perhaps the proportion of independent directors is too low to influence the board, their experience inadequate or independence questionable. These conclusions from Jordan may well apply to other developing countries. In addition, the results of our study show that the presence of a large shareholder exacerbates REM and AEM. This in turn raises the need for strengthening the rights of minority shareholders. CEO-duality is seen to impair board independence and increase REM, justifying the 2009 JCGC recommendation. The reported ineffective role of BIG 4 audit firms in mitigating earnings manipulation is concerning.

Notwithstanding the steps taken to ensure the robustness of the results of the current paper, some potential limitations remain. For example; separating the consequences of opportunistic REM from those of optimal business activities is difficult. Future research that allows researchers to separate optimal business actions from managerial opportunism associated with REM and AEM is needed. Further, in the present study CG variables are treated as exogenously determined. However, there is a possibility that EM and some of those variables 
are endogenously determined (Denis, 2001). Future research investigating this issue further would be worthwhile.

Our study adds to accounting literature considering the characteristics of the board and of ownership structure, extending this line of research on EM and CG mechanisms to a developing country, Jordan. Further Jordanian CG research should include a study of the impact of the introduction of the 2009 code and whether this led to a step-change in the importance and impact of these CG indicators. In examining Jordan and, of course, recognising limitations in applying these results to other countries, this study highlights the need for further research undertaking similar investigations into other emerging markets in order that the literature develops understanding and provides policy guidance for the majority of the world that is deemed "developing". The issues of data limitation in quality, variety and quantity need to be faced rather than avoided by a continuing focus on data-rich developed markets. 


\begin{tabular}{|c|c|}
\hline Variables & Definition \\
\hline \multicolumn{2}{|c|}{ Earnings Management Variables } \\
\hline ABCFO & $\begin{array}{l}\text { Abnormal cash flows from operations, measured as deviations from the } \\
\text { predicted values from the corresponding industry-year regression. }\end{array}$ \\
\hline ABPROD & $\begin{array}{l}\text { Abnormal production costs, measured as deviations from the predicted values } \\
\text { from the corresponding industry-year regression. }\end{array}$ \\
\hline ABDISXP & $\begin{array}{l}\text { Abnormal discretionary expenses, measured as deviations from the predicted } \\
\text { values from the corresponding industry-year regression. }\end{array}$ \\
\hline REM_ALL & $\begin{array}{l}\text { Aggregate REM proxy, the sum of the additive inverse of abnormal cash } \\
\text { flows from operations, the additive inverse of abnormal discretionary } \\
\text { expenses, and abnormal production costs. }\end{array}$ \\
\hline REM1 & $\begin{array}{l}\text { Aggregate REM proxy 1, the sum of abnormal production costs and additive } \\
\text { inverse of abnormal cash flows from operations. }\end{array}$ \\
\hline \multirow[t]{2}{*}{ REM2 } & $\begin{array}{l}\text { Aggregate REM proxy 2, the sum of the additive inverse of abnormal cash } \\
\text { flows from operations and the additive inverse of abnormal discretionary } \\
\text { expenses. }\end{array}$ \\
\hline & $\begin{array}{l}\text { Abnormal discretionary accruals, measured as deviations from the predicted } \\
\text { values from the corresponding industry-year regression. }\end{array}$ \\
\hline ABDACC & $\begin{array}{l}\text { Abnormal discretionary accruals, measured as deviations from the predicted } \\
\text { values from the corresponding industry-year regression. }\end{array}$ \\
\hline \multicolumn{2}{|c|}{ Corporate Governance Variables } \\
\hline BSIZE & Board size, equal to a total number of directors on the board. \\
\hline BIND & $\begin{array}{l}\text { Board independence, equal to the proportion of independent directors on the } \\
\text { board to the total number of directors on the board. }\end{array}$ \\
\hline CEODUAL & $\begin{array}{l}\text { CEO-duality, is a dummy variable equals } 1 \text { if } \mathrm{CEO} \text { and the chairman positons } \\
\text { are held by the same person, } 0 \text { otherwise. }\end{array}$ \\
\hline MANGOW & $\begin{array}{l}\text { Managerial ownership, equal to the proportion of shares owned by board } \\
\text { members and their relatives to the total number of shares outstanding. }\end{array}$ \\
\hline INSTOW & $\begin{array}{l}\text { Institutional ownership, equal to the proportion of common shares held by the } \\
\text { institutions. }\end{array}$ \\
\hline FOREOW & $\begin{array}{l}\text { Foreign ownership, equal to the proportion of common shares held by the } \\
\text { foreign investors (non-Jordanian). }\end{array}$ \\
\hline LARGST & $\begin{array}{l}\text { Largest shareholder, equal to the proportion of common shares held by the } \\
\text { largest shareholder who does not serve as an executive officer or director. }\end{array}$ \\
\hline \multicolumn{2}{|c|}{ Control Variables } \\
\hline ROA & Return on assets, measured as net income divided by total assets. \\
\hline FSIZE & Firm size, equal to the natural $\log$ of total assets. \\
\hline MKTB & Market to book ratio. \\
\hline LEV & Leverage, measured as total liabilities scaled by total assets. \\
\hline BIG4 & $\begin{array}{l}\text { Dummy variable set one if the firm is audited by the big } 4 \text {-audit firm, zero } \\
\text { otherwise. }\end{array}$ \\
\hline \multicolumn{2}{|c|}{ Additional Variables Used to Test for Potential Substitution between REM and AEM } \\
\hline MKTSH & $\begin{array}{l}\text { Market share, measured as the percentage of a company's sales to the total } \\
\text { sales of its industry. }\end{array}$ \\
\hline $\mathbf{N O A}_{t-1}$ & $\begin{array}{l}\text { Net Operating Assets, is a dummy variable that equals } 1 \text { if the net operating } \\
\text { assets (i.e., shareholders' equity less cash and marketable securities plus total } \\
\text { debt) at the beginning of the year divided by lagged sales are above the } \\
\text { median of the corresponding industry-year, and } 0 \text { otherwise. }\end{array}$ \\
\hline
\end{tabular}




\section{References}

Abed, S., Al-Attar, A. and Suwaidan, M. (2012), "Corporate governance and earnings management: Jordanian evidence", International Business Research, Vol. 5 No.1, pp. 216-225.

Aharony, J., Lee, C. J. and Wong, T. J. (2000), "Financial packaging of IPO firms in China", Journal of Accounting Research, Vol. 38 No.1, pp. 103-126.

Al-Fayoumi, N., Abuzayed, B. and Alexander, D. (2010), "Ownership structure and earnings management in emerging markets: The case of Jordan", International Research Journal of Finance and Economics, Vol. 38 No. 1, pp. 28-47.

Alghamdi,S. (2012), "Investigation into earnings management practices and the role of corporate governance and external audit in emerging markets: empirical evidence from Saudi listed companies". PhD Thesis, Durham University, UK.

Alhadab, M., Clacher, I. and Keasey, K. (2015), "Real and accrual earnings management and IPO failure risk", Accounting and Business Research, Vol. 45 No. 1, pp. 55-92.

Ali, S. M., Salleh, N. M. and Hassan, M. S. (2008), "Ownership structure and earnings management in Malaysian listed companies: the size effect", Asian Journal of Business and Accounting, Vol. 1 No. 2, pp. 89-116.

ASE (2002). Directives for Listing Securities on the Amman Stock Exchange (2002), Available at: http://www.ase.com.jo/en/listing-securities-directives. (Accessed on: October 2016).

ASE Annual Report (2015), "Amman Stock Exchange”. Available at: http://ase.com.jo/sites/default/files/Annual_Report_\%202015_en.pdf. (Accessed on: September 2016).

Ball, R. and Shivakumar, L. (2008), "How much new information is there in earnings?", Journal of Accounting Research, Vol. 46 No. 5, pp. 975-1016.

Beasley, M. S. (1996), "An empirical analysis of the relation between the board of director composition and financial statement fraud", Accounting Review, Vol. 71 No. 4, pp. 443-465.

Ben-Nasr, H., Boubakri, N. and Cosset, J. (2015), "Earnings quality in privatized firms: The role of state and foreign owners", Journal of Accounting and Public Policy, Vol.34(4), pp. 392416.

Bushee, B. J. (1998), "The influence of institutional investors on myopic R\&D investment behavior", The Accounting Review, Vol.73 No. 3, pp. 305-333.

Cadbury, A. (1992), "Report of the committee on the financial aspects of corporate governance”. Gee.

Chen, C., Huang, S. and Fan, H. (2012), "Complementary association between real activities and accruals-based manipulation in earnings reporting", Journal of Economic Policy Reform, Vol.15 No. 2, pp. 93-108.

Chen, J. J. and Zhang, H. (2014), "The impact of the corporate governance code on earnings management-Evidence from Chinese listed companies", European Financial Management, Vol.20 No. 3, pp. 596-632. 
Cheng, Q., Luo, T. and Yue, H. (2013), "Managerial incentives and management forecast precision", The Accounting Review, Vol. 88 No. 5, pp. 1575-1602.

Chung, R., Firth, M. and Kim, J. (2002), "Institutional monitoring and opportunistic earnings management", Journal of Corporate Finance, Vol. 8 No. 1, pp. 29-48.

Cohen, D. A., Dey, A. and Lys, T. Z. (2008), "Real and Accrual-Based Earnings Management in the Pre- and Post-Sarbanes-Oxley Periods", The Accounting Review, Vol.83(3), pp. 757-787.

Cohen, D. A. and Zarowin, P. (2010), "Accrual-based and real earnings management activities around seasoned equity offerings", Journal of Accounting and Economics, Vol.50 No. 1, pp. 219.

Cohen, J., Krishnamoorthy, G. and Wright, A. M. (2002), "Corporate governance and the audit process", Contemporary Accounting Research, Vol.19 No. 4, pp. 573-594.

Dalton, D. R., Daily, C. M., Ellstrand, A. E. and Johnson, J. L. (1998), "Meta-analytic reviews of board composition, leadership structure, and financial performance", Strategic Management Journal, Vol. 19 No. 3, pp. 269-290.

Davis, J. H., Schoorman, F. D. and Donaldson, L. (1997), "Toward a stewardship theory of management", Academy of Management Review, Vol.22 No. 1, pp. 20-47.

Dechow, P. M. and Skinner, D. J. (2000), "Earnings management: Reconciling the views of accounting academics, practitioners, and regulators", Accounting Horizons, 14(2), pp. 235-250.

Dechow, P. M., Sloan, R. G. and Sweeney, A. P. (1996), "Causes and consequences of earnings manipulation: An analysis of firms subject to enforcement actions by the SEC", Contemporary Accounting Research, Vol.13 No. 1, pp. 1-36.

Dechow, P. M., Sloan, R. G. and Sweeney, A. P. (1995), “Detecting earnings management”, The Accounting Review, Vol. 70 No. 2, pp. 193-225.

Denis, D. K. (2001), “Twenty-five years of corporate governance research... and counting", Review of Financial Economics, 10(3), pp. 191-212.

Demsetz, H. and Lehn, K. (1985), "The structure of corporate ownership: Causes and consequences", Journal of Political Economy, Vol.93 No. 6, pp. 1155-1177.

Doukakis, L. C. (2014), "The effect of mandatory IFRS adoption on real and accrual-based earnings management activities", Journal of Accounting and Public Policy, Vol.33 No. 6, pp. $551-572$.

Dvorak, T. (2005), "Do domestic investors have an information advantage? Evidence from Indonesia", The Journal of Finance, Vol. 60 No. 2, pp. 817-839.

Ewert, R. and Wagenhofer, A. (2005), "Economic effects of tightening accounting standards to restrict earnings management", The Accounting Review, Vol. 80 No. 4, pp. 1101-1124.

Fama, E. F. (1980), "Agency Problems and the Theory of the Firm", The Journal of Political Economy, Vol.88 No. 2, pp. 288-307.

Fama, E. F. and Jensen, M. C. (1983), "Separation of ownership and control", The Journal of Law \& Economics, Vol. 26 No. 2, pp. 301-325. 
Garven, S. (2015), "The Effects of Board and Audit Committee Characteristics on Real Earnings Management: Do Boards and Audit Committees Play a Role in Its Promotion or Constraint?", Academy of Accounting and Financial Studies Journal, Vol.19 No. 1, pp. 67-84.

Ge, W. and Kim, J. (2014), "Boards, takeover protection, and real earnings management", Review of Quantitative Finance and Accounting, Vol. 43 No. 4, pp. 651-682.

Ghosh, A., Marra, A. and Moon, D. (2010), "Corporate Boards, Audit Committees, and Earnings Management: Pre- and Post-SOX Evidence", Journal of Business Finance \& Accounting, Vol. 37 No. 9-10, pp. 1145-1176.

Goh, J., Lee, H. and Lee, J. (2013), "Majority shareholder ownership and real earnings management: evidence from Korea", Journal of International Financial Management \& Accounting, Vol.24 No. 1, pp. 26-61.

Gonzalez, J. S. and Garcia-Meca, E. (2014), "Does corporate governance influence earnings management in Latin American markets?", Journal of Business Ethics, Vol.121 No. 3, pp. 419440 .

Graham, J. R., Harvey, C. R. and Rajgopal, S. (2005), "The Economic Implications of Corporate Financial Reporting", Journal of Accounting and Economics, Vol.40 No. 1, pp. 3.

Guo, J., Huang, P., Zhang, Y. and Zhou, N. (2015), "Foreign ownership and real earnings management: Evidence from Japan", Journal of International Accounting Research, Vol.14 No. 2, pp. 185-213.

Hashim, H. A. and Devi, S. S. (2008), "Board independence, CEO duality and accrual management: Malaysian evidence", Asian Journal of Business and Accounting, Vol.1 No. 1, pp. $27-46$.

Hayes, A. F. (2009), “Statistical methods for communication science”. Routledge.

Healy, P. M. and Wahlen, J. M. (1999), "A review of the earnings management literature and its implications for standard setting", Accounting Horizons, Vol. 13 No. 4, pp. 365-383.

ILO (2013), "International Labour Office, Independent Evaluation of the ILO's Strategy to Promote Decent Work in the Arab Region: A Cluster Evaluation of Jordan, Lebanon and the Occupied Palestinian Territory". Available at: http://www.ilo.org/wcmsp5/groups/public/--ed_mas/---eval/documents/publication/wcms_226356.pdf. (Accessed on: September 2016).

JCGC (2009), "Corporate Governance Code for Shareholding Companies Listed on the Amman Stock Exchange”. Available at: http://jsc.gov.jo/library/634365426651890968.pdf. (Accessed on: September 2015).

Jensen, M. C. (1993), "The modern industrial revolution, exit, and the failure of internal control systems", The Journal of Finance, Vol.48 No. 3, pp. 831-880.

Jensen, M. C. and Meckling, W. H. (1976), "Theory of the firm: Managerial behavior, agency costs and ownership structure", Journal of Financial Economics, Vol. 3 No. 4, pp. 305-360.

Jiang, J. (2008), "Beating earnings benchmarks and the cost of debt", The Accounting Review, Vol.83 No. 2, pp. 377-416.

Jung, K. and Kwon, S. Y. (2002), “Ownership structure and earnings informativeness: Evidence from Korea”, The International Journal of Accounting, Vol.37 No. 3, pp. 301-325. 
Kang, S. and Kim, Y. (2012), "Effect of corporate governance on real activity-based earnings management: evidence from Korea", Journal of Business Economics and Management, Vol.13 No. 1, pp. 29-52.

Khanna, T. and Palepu, K. (2000), "Emerging Market Business Groups, Foreign Intermediaries, and Corporate Governance", NBER Chapters, , pp. 265-294.

Klein, A. (2002), "Audit committee, board of director characteristics, and earnings management", Journal of Accounting and Economics, Vol. 33 No. 3, pp. 375-400.

Kothari, S. P., Leone, A. and Wasley, C. (2005), "Performance matched discretionary accrual measures", Journal of Accounting and Economics, Vol. 39 No. 1, pp. 163-197.

Kuo, J., Ning, L. and Song, X. (2014), "The Real and Accrualbased Earnings Management Behaviors: Evidence from the Split Share Structure Reform in China", International Journal of Accounting, Vol.49 No. 1, pp. 101-136.

Lemmon, M. L. and Lins, K. V. (2003), "Ownership structure, corporate governance, and firm value: Evidence from the East Asian financial crisis", The Journal of Finance, Vol.58 No. 4,

Liu, H. and Fong, M. W. (2010), "Board characteristics of medium and large Chinese companies", Corporate Governance: The International Journal of Business in Society, Vol.10 No. 2, pp. 163-175.

Liu, J. and Tsai, C. (2015), "Board Member Characteristics and Ownership Structure Impacts on Real Earnings Management: Evidence from Taiwan", Accounting and Finance Research, Vol. 4 No. 4, pp. 84-96.

Monks, R. A. and Minow N. (2008), “Corporate governance”. Cambridge, MA.

Morck, R., Shleifer, A. and Vishny, R. W. (1988), "Management ownership and market valuation: An empirical analysis", Journal of Financial Economics, Vol. 20, pp. 293-315.

OECD (2006), "MENA-OECD Investment Programme National Investment Reform Agenda Workshop for the Hashemite Kingdom of Jordan". Available at: http://www.oecd.org/dataoecd/4/29/38148879.pdf. (Accessed on: September 2015).

OECD (2004), "OECD principles of corporate governance”. Available at: https://www.oecd.org/corporate/ca/corporategovernanceprinciples/31557724.pdf.

(Accessed on: September 2015).

OECD Development Centre (2010), "Perspectives on Global Development: Shifting Wealth". Available at: http://www.oecd.org/dev/pgd/economydevelopingcountriessettoaccountfornearly60ofworldgd pby2030accordingtonewestimates.htm. (Accessed on: March 2017).

Osma, B. G. (2008), "Board independence and real earnings management: The case of R\&D expenditure", Corporate Governance: An International Review, Vol.16 No. 2, pp. 116-131.

Peasnell, K. V., Pope, P. F. and Young, S. (2005), "Board monitoring and earnings management: Do outside director's influence abnormal accruals?", Journal of Business Finance \& Accounting, Vol.32 No. 7-8, pp. 1311-1346.

Perry, S. and Grinaker, R. (1994), "Earnings expectations and discretionary research and develop", Accounting Horizons Vol., 8 No. 4, pp. 43-51. 
Rahman, R. A. and Ali, F. H. M. (2006), "Board, audit committee, culture and earnings management: Malaysian evidence", Managerial Auditing Journal, Vol.21 No. 7, pp. 783-804.

Roodposhti, F. R. and Chashmi, S. N. (2011), "The impact of corporate governance mechanisms on earnings management", African Journal of Business Management, Vol. 5 No. 11, pp. 4143.

ROSC (2004), "Report on the Observance of Standards and Cods, Corporate Governance Country Assessment, Jordan”. Available at: www.worldbank.org/ifa/jorrosc cg.pdf. (Accessed on: .

Roychowdhury, S. (2006), "Earnings management through real activities manipulation", Journal of Accounting and Economics, Vol. 42 No. 3, pp. 335-370.

Shleifer, A. and Vishny, R. W. (1997), "A survey of corporate governance”, The Journal of Finance, Vol. 52 No. 2, pp. 737-783.

Sun, J. and Cahan, S. (2009), "The effect of compensation committee quality on the association between CEO cash compensation and accounting performance", Corporate Governance: An International Review, Vol. 17 No. 2, pp. 193-207.

Sun, J. and Liu, G. (2016), “Does analyst coverage constrain real earnings management?", The Quarterly Review of Economics and Finance, Vol. 59, pp. 131-140.

Talbi, D., Omri, M. A., Guesmi, K. and Ftiti, Z. (2015), "The Role of Board Characteristics in Mitigating Management Opportunism: The Case Of Real Earnings Management", Journal of Applied Business Research, Vol. 31No. 2, pp. 661-674.

+Teshima, N. and Shuto, A. (2008), "Managerial ownership and earnings management: Theory and empirical evidence from Japan", Journal of International Financial Management \& Accounting, Vol. 19 No. 2, pp. 107-132.

Uadiale, O. M. (2012), "Earnings management and corporate governance in Nigeria", Research Journal of Finance and Accounting, Vol. 3 No. 3, pp. 1-10.

Wei, G. (2007), "Ownership structure, corporate governance and company performance in China", Asia Pacific Business Review, Vol. 13 No. 4, pp. 519-545.

World Bank (2004), "Report on the observance of standards and codes (ROSC) - accounting and auditing : Jordan". Available at: http://documents.worldbank.org/curated/en/323971468272977829/Report-on-the-observanceof-standards-and-codes-ROSC-accounting-and-auditing-Jordan. (Accessed on: November 2016).

World Bank (2016), "Doing business report". Available at: http://www.doingbusiness.org/custom-query\#Economies. (Accessed on: November 2016)

Xu, R. Z., Taylor, G. K. and Dugan, M. T. (2007), "Review of real earnings management literature", Journal of Accounting Literature, Vol. 26, pp. 195.

Young, M. N., Peng, M. W., Ahlstrom, D., Bruton, G. D. and Jiang, Y. (2008), "Corporate governance in emerging economies: A review of the principal-principal perspective", Journal of Management Studies, Vol. 45 No. 1, pp. 196-220. 
Zalata, A. and Roberts, C. (2015), "Internal Corporate Governance and Classification Shifting Practices: An Analysis of UK Corporate Behavior", Journal of Accounting, Auditing \& Finance, Vol. 31 No. 1, pp. 51-78.

Zang, A. (2012), "Evidence on the Trade-Off between Real Activities Manipulation and Accrual-Based Earnings Management", The Accounting Review, Vol. 87 No. 2, pp. 675. 
Table 1: Sample Selection Procedure

\begin{tabular}{|c|c|c|c|c|c|c|}
\hline Description & 2010 & 2011 & 2012 & 2013 & 2014 & Pooled \\
\hline Initial sample & 251 & 251 & 251 & 251 & 251 & 1255 \\
\hline \multicolumn{7}{|l|}{ Excluded: } \\
\hline Financial sector companies & (108) & (108) & (108) & $(108)$ & $(108)$ & $(540)$ \\
\hline $\begin{array}{l}\text { Missing annual reports and } \\
\text { /or corporate governance } \\
\text { data }\end{array}$ & $(35)$ & (35) & $(35)$ & (35) & (35) & $(175)$ \\
\hline Final sample & 108 & 108 & 108 & 108 & 108 & 540 \\
\hline
\end{tabular}


Table 2: Descriptive Statistics

Panel A: Model parameters

\begin{tabular}{|c|c|c|c|c|}
\hline & $\mathrm{CFO}_{t} / \mathrm{A}_{\mathrm{t}-1}$ & PROD $_{t} / \mathbf{A}_{t-1}$ & DISXP $_{t} / A_{t-1}$ & ABDACC/ $\mathbf{A}_{t-1}$ \\
\hline \multirow[t]{2}{*}{ Intercept } & $0.0503^{*}$ & -0.0139 & 0.0280 & $-0.0495^{*}$ \\
\hline & (1.668) & $(-0.702)$ & $(3.687)^{* * *}$ & $(-1.711)$ \\
\hline \multirow[t]{2}{*}{$1 / A_{t-1}$} & $-268789.2 * *$ & -31709.5 & 144019.3 & 109235.6 \\
\hline & $(-2.423)$ & $(-3.140)^{* * *}$ & $(5.391)^{* * *}$ & $(0.964)$ \\
\hline \multirow[t]{2}{*}{$S_{t} / A_{t-1}$} & 0.0472 & 0.7674 & - & - \\
\hline & (0.784) & $(13.183)^{* * *}$ & & \\
\hline \multirow[t]{2}{*}{$\mathbf{S}_{\mathrm{t}-1} / \mathbf{A}_{\mathrm{t}-1}$} & - & - & 0.0737 & - \\
\hline & & & $(3.627)^{* * *}$ & \\
\hline \multirow[t]{2}{*}{$\Delta \mathbf{S}_{\mathbf{t}} / \mathbf{A}_{\mathbf{t}-1}$} & $-0.1137 *$ & 0.0415 & - & - \\
\hline & $(-1.627)$ & $(0.321)$ & & \\
\hline \multirow[t]{2}{*}{$\Delta \mathbf{S}_{\mathbf{t}-1} / \mathbf{A}_{\mathbf{t}-1}$} & & -0.0414 & - & - \\
\hline & & $(-0.333)$ & & \\
\hline \multirow[t]{2}{*}{$\left.\left(\Delta \operatorname{REV}_{\mathrm{it}}-\Delta \mathrm{REC}_{\mathrm{it}}\right) / \mathrm{A}_{\mathrm{it}-1}\right)$} & - & - & - & -0.0069 \\
\hline & & & & $(-0.124)$ \\
\hline \multirow[t]{2}{*}{$\left(\mathbf{P P E}_{\text {it }} / \mathbf{A}_{\text {it-1 }}\right)$} & - & - & - & 0.0422 \\
\hline & & & & $(0.493)$ \\
\hline \multirow[t]{2}{*}{ ROA } & - & - & - & 0.5935 \\
\hline & & & & $(4.455)^{* * *}$ \\
\hline Adjusted $\mathbf{R}^{2}$ & 0.400 & 0.879 & 0.254 & 0.574 \\
\hline
\end{tabular}

***, **, * Indicate significance at 1 percent, 5 percent, and 10 percent levels in a two-tailed test, respectively. This table reports the estimated parameters in the following regressions:

(a) $\frac{C F O_{i t}}{T A_{i t-1}}=a_{0}+\beta 1 \frac{1}{T A_{i t-1}}+\beta 2 \frac{S_{i t}}{T A_{i t-1}}+\beta 3 \frac{\Delta S_{i t}}{T A_{i t-1}}+\varepsilon_{i t}$

(b) $\frac{P R O D_{i t}}{T A_{i t-1}}=a_{0}+\beta 1 \frac{1}{T A_{i t-1}}+\beta 2 \frac{S_{i t}}{T A_{i t-1}}+\beta 3 \frac{\Delta S_{i t}}{T A_{i t-1}}+\beta 4 \frac{\Delta S_{i t-1}}{T A_{i t-1}}+\varepsilon_{i t}$

(c) $\frac{D I S X P_{i t}}{T A_{i t}-1}=a_{0}+\beta 1 \frac{1}{T A_{i t-1}}+\beta 2 \frac{s_{i t-1}}{T A_{i t-1}}+\varepsilon_{i t}$

$(d) \frac{T A C C_{i t}}{T A_{i t-1}}=a_{0}+\beta 1 \frac{1}{T A_{i t-1}}+\beta 2 \frac{\Delta R E V_{i t}-\Delta R E C_{i t}}{T A_{i t-1}}+\beta 3 \frac{P P E_{i t}}{T A_{i t-1}}+\beta 4 R O A_{i t}+\varepsilon_{i t}$

The regressions are estimated for every industry every year. One-digit SIC codes are used to define industries. There are 30 separate industry-years over 2010-2014. The table reports the mean coefficient across all industry-years and t-statistics calculated using the standard error of the mean across industry-years. The table also reports the mean $\mathrm{R}^{2} \mathrm{~s}$ (across industry-years) for each of these regressions. 


\begin{tabular}{lccccccc}
\hline Variables & Mean & Median & $\begin{array}{c}\text { Standard } \\
\text { Deviation }\end{array}$ & $\mathbf{2 5 \%}^{\mathbf{3}}$ & $\mathbf{7 5 \%}$ & Skewness & Kurtosis \\
Corporate Governance: Real and ferent Earnings Management Variables & & \\
\multicolumn{7}{l}{ Earnings Management Variables } \\
ABCFO & -0.0000 & -0.0024 & 0.0774 & -0.0474 & 0.0462 & -0.1261 & 4.3230 \\
ABPROD & -0.0000 & 0.0065 & 0.0913 & -0.0396 & 0.0553 & -0.5873 & 4.7871 \\
ABDISXP & 0.0000 & 0.0130 & 0.0577 & -0.0177 & 0.0330 & -1.1400 & 4.3122 \\
REM_ALL & 0.0000 & 0.0154 & 0.1696 & -0.0812 & 0.1044 & -0.6664 & 4.0760 \\
REM1 & 0.0000 & 0.0064 & 0.1362 & -0.0701 & 0.0782 & -0.4141 & 4.1419 \\
REM2 & -0.0000 & 0.0070 & 0.1004 & -0.0512 & 0.0627 & -0.3996 & 3.4647 \\
ABDACC & -0.0000 & 0.0000 & 0.0645 & -0.0347 & 0.0334 & 0.0559 & 4.3197 \\
Corporate Governance Variables & & & & & & \\
BIND & 0.3425 & 0.2860 & 0.2579 & 0.1820 & 0.4620 & 0.6251 & 2.6684 \\
BSIZE & 8.0925 & 8.0000 & 2.1799 & 7.0000 & 9.0000 & 0.4202 & 2.6465 \\
CEODUAL & 0.1703 & 0.0000 & 0.3763 & 0.0000 & 0.0000 & 1.7535 & 4.0749 \\
MANGOW & 0.5068 & 0.5215 & 0.2762 & 0.2793 & 0.7307 & -0.1220 & 1.9458 \\
INSTOW & 0.3945 & 0.3775 & 0.2906 & 0.1543 & 0.6180 & 0.2412 & 1.9033 \\
FOREOW & 0.1720 & 0.0793 & 0.2235 & 0.0140 & 0.2120 & 1.7301 & 5.3361 \\
LARGST & 0.3618 & 0.3080 & 0.2207 & 0.1843 & 0.4900 & 1.0025 & 3.3774 \\
Control Variables & & & & & & & \\
FSIZE & 16.9198 & 16.9435 & 1.3386 & 15.9922 & 17.7538 & 0.3395 & 3.0991 \\
LEV & 0.3380 & 0.3001 & 0.2277 & 0.1660 & 0.4492 & 0.8356 & 3.1195 \\
ROA & 0.0054 & 0.0158 & 0.0841 & -0.0274 & 0.0502 & -0.7618 & 3.8948 \\
MKTB & 1.3156 & 0.9900 & 0.9200 & 0.6800 & 1.6700 & 1.4227 & 4.5082 \\
BIG4 & 0.3777 & 0.0000 & 0.4852 & 0.0000 & 1.0000 & 0.5041 & 1.2542 \\
Potential Substitution between REM and AEM Variables & & & & \\
MKTSH & 0.0441 & 0.0106 & 0.0850 & 0.0019 & 0.0419 & 3.0290 & 12.0160 \\
NOA & 0.4685 & 0.0000 & 0.4994 & 0.0000 & 1.0000 & 0.1261 & 1.0159 \\
\hline
\end{tabular}

This table presents the descriptive statistics of the variables in the regression models used to test the hypotheses. For the purposes of illustration, variables representing abnormal operational cash flow and abnormal discretionary expenses are multiplied by -1 . Accordingly, high values for the proxies for abnormal cash flow (ABCFO) and abnormal discretionary expenses (ABDISXP) indicate greater degrees of REM. The sample consists of 540 firmyears observation during the period 2010-2014.

3 Similar to other studies including Zang (2012) and Ge and Kim (2014), to present the range of data, the current study does not focus on the Max and Minimum value as this will lead to a range that is not representative of the variability within the data because it depends on two most extreme values within data. 
Table 3: Correlation Matrix

\begin{tabular}{|c|c|c|c|c|c|c|c|c|c|c|c|c|}
\hline Variables & BIND & BSIZE & CEODUL & MANGOW & INSTOW & FOREOW & LARGST & FSIZE & $\overline{\text { LEV }}$ & ROA & MKTB & BIG4 \\
\hline BIND & 1 & & & & & & & & & & & \\
\hline BSIZE & $-0.732 *$ & 1 & & & & & & & & & & \\
\hline CEODUL & -0.0105 & 0.0169 & 1 & & & & & & & & & \\
\hline MANGOW & -0.0187 & 0.0623 & -0.0346 & 1 & & & & & & & & \\
\hline INSTOW & $0.2047 * * *$ & $0.0758 *$ & $-0.2022 * * *$ & $0.1910 * * *$ & 1 & & & & & & & \\
\hline FOREOW & $0.2091 * * *$ & -0.0131 & 0.0652 & 0.0690 & $0.3958 * * *$ & 1 & & & & & & \\
\hline LARGST & $0.1084 *$ & $-0.1681^{* * * *}$ & $-0.1602 * * *$ & $0.2280 * * *$ & $0.4549 * * *$ & 0.0499 & 1 & & & & & \\
\hline FSIZE & -0.0124 & $0.2980 * * *$ & -0.0763 & -0.0230 & $0.2191 * * *$ & $0.2626 * * *$ & $0.1272 * * *$ & 1 & & & & \\
\hline LEV & -0.0185 & -0.0220 & $-0.1025 * *$ & $-0.1397 * * *$ & $0.0953 * *$ & $0.0840 *$ & $0.0903 * *$ & $0.3675 * * *$ & 1 & & & \\
\hline ROA & $-0.0941 * *$ & $0.0954 * *$ & $0.1336 * * *$ & $0.1512 * * *$ & 0.0315 & -0.0489 & 0.0471 & $0.3016^{* * *}$ & $-0.2626 * * *$ & 1 & & \\
\hline MKTB & -0.0229 & $0.0995 * *$ & 0.0542 & 0.0621 & $0.0757 *$ & $-0.1455 * * *$ & $0.1228 * * *$ & 0.0459 & $0.1808 * * *$ & 0.0646 & 1 & \\
\hline BIG4 & $0.1214 * * *$ & $0.2019 * * *$ & $-0.1804 * * *$ & $0.1238 * * * *$ & $0.4095 * * *$ & $0.3515^{* *}$ & 0.0222 & $0.3400^{* * * *}$ & $\mathbf{0 . 1 1 5 3}^{* * *}$ & -0.0110 & $0.0970^{* *}$ & 1 \\
\hline
\end{tabular}


Table 4: Regression Results

\begin{tabular}{|c|c|c|c|c|c|c|}
\hline Variable & $\begin{array}{c}\text { Exp. } \\
\text { sign }\end{array}$ & $\begin{array}{c}(1) \\
\text { ABCFO }\end{array}$ & $\begin{array}{c}(2) \\
\text { ABPROD }\end{array}$ & $\begin{array}{c}\text { (3) } \\
\text { ABDISXP }\end{array}$ & $\begin{array}{c}\text { (4) } \\
\text { REM_ALL }\end{array}$ & $\begin{array}{c}\text { (5) } \\
\text { ABDACC }\end{array}$ \\
\hline BIND & - & $2.35 * *$ & $2.32 * *$ & $-1.88^{*}$ & $2.92 * * *$ & $2.39 * *$ \\
\hline BSIZE & - & -1.29 & -1.31 & $4.53^{* * * *}$ & -0.76 & -0.55 \\
\hline CEODUAL & + & 0.033 & $1.98^{*}$ & 0.97 & $2.04 * *$ & -0.93 \\
\hline MANGOW & - & $-1.78^{*}$ & -1.06 & 0.66 & -1.53 & $-2.67 * * *$ \\
\hline INSTOW & - & $-2.17 * *$ & 0.01 & $-2.38 * *$ & $-2.58 * * *$ & $-2.02 * *$ \\
\hline FOREOW & - & -0.12 & 0.46 & -0.21 & 0.72 & -0.65 \\
\hline LARGST & + & $3.71^{* * *}$ & 1.28 & -0.04 & $2.17 * *$ & $2.97 * * *$ \\
\hline FSIZE & $?$ & $-2.13^{* *}$ & 1.14 & 1.37 & 1.40 & $-1.65^{*}$ \\
\hline LEV & $?$ & $2.74 * * *$ & 0.41 & -1.02 & 0.73 & $3.25 * * *$ \\
\hline ROA & $?$ & $1.94 *$ & $2.76^{* * *}$ & 1.04 & $1.65^{*}$ & 1.02 \\
\hline МКТВ & $?$ & 0.97 & $1.94^{*}$ & $2.30 * *$ & $2.41 * *$ & -0.61 \\
\hline BIG4 & $?$ & 1.46 & 0.26 & 1.15 & 0.90 & 0.56 \\
\hline INDDUM & $+/-$ & Inc. & Inc. & Inc. & Inc. & Inc. \\
\hline $\begin{array}{l}\text { YEARDUM } \\
\text { Adj. R-squared }\end{array}$ & $+/-$ & $\begin{array}{l}\text { Inc. } \\
9.14 \%\end{array}$ & $\begin{array}{c}\text { Inc. } \\
23.47 \%\end{array}$ & $\begin{array}{c}\text { Inc. } \\
27.01 \%\end{array}$ & $\begin{array}{c}\text { Inc. } \\
12.84 \%\end{array}$ & $\begin{array}{c}\text { Inc. } \\
25.38 \%\end{array}$ \\
\hline F test & & $\begin{array}{l}F(21,518) \\
=\quad 3.58\end{array}$ & $\begin{array}{l}F(21,518) \\
=\quad 69.39\end{array}$ & $\begin{array}{l}F(21,518) \\
=\quad 21.75\end{array}$ & $\begin{array}{l}F(21,518) \\
=\quad 37.85\end{array}$ & $\begin{array}{r}F(21,518) \\
67.73\end{array}$ \\
\hline
\end{tabular}

***, **, * Indicate significance at 1 percent, 5 percent, and 10 percent levels in a two-tailed test, respectively. See "Appendix 1" for variable definitions. 
Table 5: Results of Multivariate Regression to Test for the Potential Substitution

\begin{tabular}{|c|c|c|c|c|c|c|c|}
\hline \multirow[b]{2}{*}{ Variables } & \multirow[b]{2}{*}{$\begin{array}{l}\text { Exp. } \\
\text { sign }\end{array}$} & \multicolumn{2}{|c|}{ REM_ALL } & \multicolumn{2}{|c|}{ REM1 } & \multicolumn{2}{|c|}{ REM2 } \\
\hline & & Coefficients & t. Statistic & Coefficients & t. Statistic & Coefficients & t. Statistic \\
\hline AEM & - & 0.341 & $4.97 * * *$ & 0.415 & $6.61 * * *$ & 0.470 & $8.79 * * *$ \\
\hline BIND & - & 0.061 & $2.40 * *$ & 0.074 & $3.13 * * *$ & 0.035 & $1.85^{*}$ \\
\hline BSIZE & - & -0.002 & -0.84 & -0.006 & $-2.31 * *$ & -0.001 & -0.90 \\
\hline CEODUAL & + & 0.042 & $2.40 * *$ & 0.033 & $1.99 * *$ & 0.034 & $2.51 * *$ \\
\hline MANGOW & - & -0.014 & -0.61 & -0.014 & -0.66 & 0.008 & 0.47 \\
\hline INSTOW & - & -0.059 & $-1.97 * *$ & -0.032 & -1.13 & -0.065 & $-2.78 * * *$ \\
\hline FOREOW & - & 0.019 & 0.57 & 0.008 & 0.27 & 0.003 & 0.12 \\
\hline LARGST & + & 0.042 & 1.25 & 0.039 & 1.16 & 0.018 & 0.68 \\
\hline FSIZE & - & 0.009 & 1.48 & 0.005 & 1.01 & -0.002 & 0.62 \\
\hline MKTB & + & 0.018 & $2.57 * *$ & 0.012 & $1.87 *$ & 0.014 & $2.67 * * *$ \\
\hline MKTSH & + & 0.171 & $1.91 *$ & 0.105 & 1.08 & 0.192 & $2.71 * * *$ \\
\hline NOA & + & -0.008 & -0.67 & -0.001 & -0.14 & 0.005 & 0.55 \\
\hline BIG4 & - & 0.009 & 0.63 & 0.010 & -0.77 & 0.018 & 1.56 \\
\hline INDDUM & $+/-$ & Inc. & Inc. & Inc. & Inc. & Inc. & Inc. \\
\hline $\begin{array}{l}\text { YEARDUM } \\
\text { _Cons }\end{array}$ & $+/-$ & $\begin{array}{c}\text { Inc. } \\
0.0893652\end{array}$ & $\begin{array}{l}\text { Inc. } \\
.87\end{array}$ & $\begin{array}{c}\text { Inc. } \\
0.1310107\end{array}$ & $\begin{array}{l}\text { Inc. } \\
1.39\end{array}$ & $\begin{array}{c}\text { Inc. } \\
0.1835484\end{array}$ & $\begin{array}{c}\text { Inc. } \\
2.35^{* *}\end{array}$ \\
\hline $\begin{array}{l}\text { Adj R- } \\
\text { squared }\end{array}$ & & \multicolumn{2}{|c|}{$17.13 \%$} & \multicolumn{2}{|c|}{$17.94 \%$} & \multicolumn{2}{|c|}{$22.66 \%$} \\
\hline
\end{tabular}

***,**,* Indicate significance at 1 percent, 5 percent, and 10 percent levels in a two-tailed test, respectively. See "Appendix 1" for variable definitions. 
Table 6: Governance Composite Score, Robustness Checks

\begin{tabular}{|c|c|c|c|c|c|c|}
\hline Variable & $\begin{array}{l}\text { Exp. } \\
\text { sign }\end{array}$ & $\begin{array}{c}\text { (1) } \\
\text { ABCFO }\end{array}$ & $\begin{array}{c}(2) \\
\text { ABPROD }\end{array}$ & $\begin{array}{c}(3) \\
\text { ABDISXP }\end{array}$ & $\begin{array}{c}\text { (4) } \\
\text { REM_ALL }\end{array}$ & $\begin{array}{c}\text { (5) } \\
\text { ABDACC }\end{array}$ \\
\hline & & t. Statistic & t. Statistic & t. Statistic & t. Statistic & t. Statistic \\
\hline GOVSCOR & - & $-3.35 * * *$ & $-1.77 *$ & $4.35 * * *$ & $-2.59 * * *$ & $-4.80 * * *$ \\
\hline FSIZE & - & $-2.35^{* *}$ & 1.34 & $2.09 * *$ & $1.87^{*}$ & -0.54 \\
\hline LEV & + & $2.67 * * *$ & 0.23 & -1.24 & 0.10 & $2.89 * * *$ \\
\hline ROA & + & $2.17 * *$ & $3.00^{* * *}$ & 0.77 & $1.78^{*}$ & 0.69 \\
\hline MKTB & + & $1.69 *$ & $2.41 * *$ & $2.29 * *$ & $2.98 * * *$ & -0.21 \\
\hline BIG4 & + & 0.46 & 0.31 & -0.14 & -0.15 & 0.06 \\
\hline INDDUM & $+/-$ & Inc. & Inc. & Inc. & Inc. & Inc. \\
\hline YEARDUM & $+/-$ & Inc. & Inc. & Inc. & Inc. & Inc. \\
\hline Adj. R-squared & & $7.13 \%$ & $22.12 \%$ & $25.26 \%$ & $10.18 \%$ & $25.69 \%$ \\
\hline
\end{tabular}

$* * *, * *, *$ Indicate significance at 1 percent, 5 percent, and 10 percent levels in a two-tailed test, respectively. GOVSCOR is the governance composite score. See "Appendix 1" for variable definitions. 